\title{
Electromyographic and sonographic assessment of diaphragm dysfunction in patients who recovered from the COVID-19 pneumonia
}

\author{
Celal SATICI ${ }^{1}$ (ID) \\ Şenay AYDIN ${ }^{2}$ (ID) \\ Lale TUNA $^{3}$ (ID) \\ Gizem KÖYBAȘI ${ }^{1}$ (ID) \\ Filiz $\operatorname{KOŞAR}^{1}$ (ID)
}

${ }^{1}$ Department of Chest Diseases, Yedikule Chest Diseases and Thoracic Surgery Training and Research Hospital, İstanbul, Turkey

${ }^{1}$ Yedikule Gögüus Hastalıkları ve Gögüs Cerrahisi Eğitim Ve Araştırma Hastanesi, Gögü̈s Hastalıkları Kliniği, Istanbul, Türkiye

${ }^{2}$ Department of Neurology, Yedikule Chest Diseases and Thoracic Surgery Training and Research Hospital, İstanbul, Turkey

2 Yedikule Gögüs Hastalıkları ve Göğüs Cerrahisi Eğitim ve Araştırma Hastanesi, Nöroloji Kliniği, İstanbul, Türkiye

${ }^{3}$ Department of Radiology, Yedikule Chest Diseases and Thoracic Surgery Training and Research Hospital, İstanbul, Turkey

3 Yedikule Göğüs Hastalıkları ve Göğüs Cerrahisi Eğitim ve Araştırma Hastanesi, Radyoloji Kliniği, İstanbul, Türkiye
Cite this article as: Satııı C, Aydın Ş, Tuna L, Köybaşı G, Kosar F. Electromyographic and sonographic assessment of diaphragm dysfunction in patients who recovered from the COVID-19 pneumonia. Tuberk Toraks 2021;69(3):425-428.

\section{Address for Correspondence (Yazışma Adresi)}

\section{Dr. Celal SATICI}

Department of Chest Diseases, Yedikule Chest Diseases and Thoracic Surgery Training and Research Hospital, ISTANBUL - TURKEY e-mail: celalsatici@yahoo.com

(C) Copyright 2021 by Tuberculosis and Thorax.

Available on-line at www.tuberktoraks.org.com
Dear Editor

Diaphragm dysfunction may occur during the course of novel coronavirus disease (COVID-19) due to critical illness myopathy or ventilator-induced diaphragm damage in critically ill patients (1). Among the patients who admitted to the intensive care unit (ICU), diaphragm fibrosis tends to be more frequent in patients with COVID-19 in ICU (2). Ventilator-induced diaphragm dysfunction (1) and critical illness myopathy in a patient with COVID-19 pneumonia prior to intubation (3) have been reported so far. However, we are not aware of any reports of diaphragm dysfunction related to less severe COVID-19. In a recent postmortem study, severe acute respiratory syndrome coronavirus-2 (SARS-CoV-2) viral RNA was found in the diaphragm (2). Although this finding could be observed in patients who have died due to COVID-19, it is expected that diaphragm dysfunction would also occur in patients who experienced a less severe disease and would be a possible reason for persistent dyspnea in patients who recovered from COVID-19 without any lasting lung parenchymal damage. 
Between December 1, 2020 and January 1, 2021, 612 patients who recovered from COVID-19 were admitted to our pandemic clinic. Of these, we surveyed 243 patients with persistent dyspnea, no apparent lung parenchymal involvement, and were diagnosed with COVID-19 at least three months ago. Diaphragm elevation on chest radiography was detected in a total of 20 patients, on chest radiography with an erect postero-anterior position, full inspiration and without artefacts. We excluded eight patients who did not have a chest radiograph before COVID-19 diagnosis and six patients in whom diaphragm elevation was already present on the chest radiograph before COVID-19 diagnosis. Finally, we included six cases (2.4\%) with de-novo diaphragm elevation after COVID-19 diagnosis and none of these cases had additional pathology on thorax computed tomography (CT) and had other risk factors such as trauma, surgery, mechanical ventilation or high flow nasal oxygen (HFNO). All these six cases underwent diaphragm ultrasonography (USG) and electromyography in order to evaluate diaphragm function. The diaphragm thickness was measured using both USG and CT. CT measurements were obtained from the crura of the elevated hemidiaphragm at the level of the origin of celiac artery origin on the axial section during inspirium (Figure 1A). Sonographic measurements were obtained at the zone of apposition in the right anterior axillary line between the $8^{\text {th }}$ and $10^{\text {th }}$ intercostal space (Figure 1B). The excursion of the diaphragm during deep breathing was evaluated with the M-mode USG with anterior subcostal view (Figure 1C). A noninvasive electrophysiological method was used in patients with the stimulation of the transcutaneous phrenic nerve and superficial recording technique over the diaphragm muscle (Figure 1D). Distal motor latency (DML) and amplitude (peak to peak) in the compound muscle action potential of the phrenic nerve (pCMAP) were determined. DML over 9 milliseconds (ms) or a DML difference of more than $1 \mathrm{~ms}$ compared to the normal side was recorded as pathological. Since the amplitude values may be variable, it was considered pathological if the value was not recorded at all or if there was a difference of $50 \%$ or more between the sides (4).

Among the six patients, the mean age was $52.6 \pm 7$ years, three were female, all had right diaphragm involvement, and all were non-smokers. All but two patients had a comorbidity, four with hypertension, and two with asthma. All these patients had been treated with nasal oxygen during their hospitalizations and had had severe disease according to WHO criteria (5). An isolated diaphragmatic crus atrophy was detected by CT measurement in case 4 whose COVID-19 diagnosis was four months ago. In the remaining five patients, diaphragm thickness was within normal limits when measured by both imaging methods. Decreased diaphragm excursion was detected in cases 2, 4, 5, and 6. Regarding electrophysiological measurements, severe prolongation in mean DML, decrease in mean amplitude, and temporal dispersion were detected in case 1. Prolongation in mean DML values was observed in cases 4 and 5, decrease in mean amplitude and temporal dispersion in case 3, and no electrophysiological activity on the elevated diaphragm side in cases 2 and 6 . In terms of respiratory capacities, forced vital capacity (FVC) was found to be decreased in cases 4 and 5, while it was preserved in the remaining four cases (Table 1). All these cases started to receive pulmonary rehabilitation program.

Diaphragm excursion measured by M-mode USG and electromyographic findings were found to be compatible in four cases. However, low electrophysiologic activity was found in cases 1 and 3 despite a normal diaphragm excursion was observed. This finding may be explained by patchy involvement of diaphragm muscles as observed in infectious myositis (6). Another possible explanation is the partial reinnervation of the phrenic nerve that develops in the subacute phase in these cases. We could not come to a conclusion as we did not perform needle electromyography. The absence of diaphragm muscle atrophy in 5/6 cases suggests that longer follow-up may be required to detect this finding.

Among a considerable number of COVID-19 patients admitted to our clinic with persistent dyspnea, we detected six cases $(2.4 \%)$ with de-novo diaphragm dysfunction. Our observation suggests that diaphragm dysfunction, although not common, may be a reason for persistent dyspnea in patients who have recovered from COVID-19. According to our case series, we recommend evaluation of diaphragm dysfunction in all COVID-19 patients with persistent dyspnea and pulmonary rehabilitation program should be considered in such patients. 


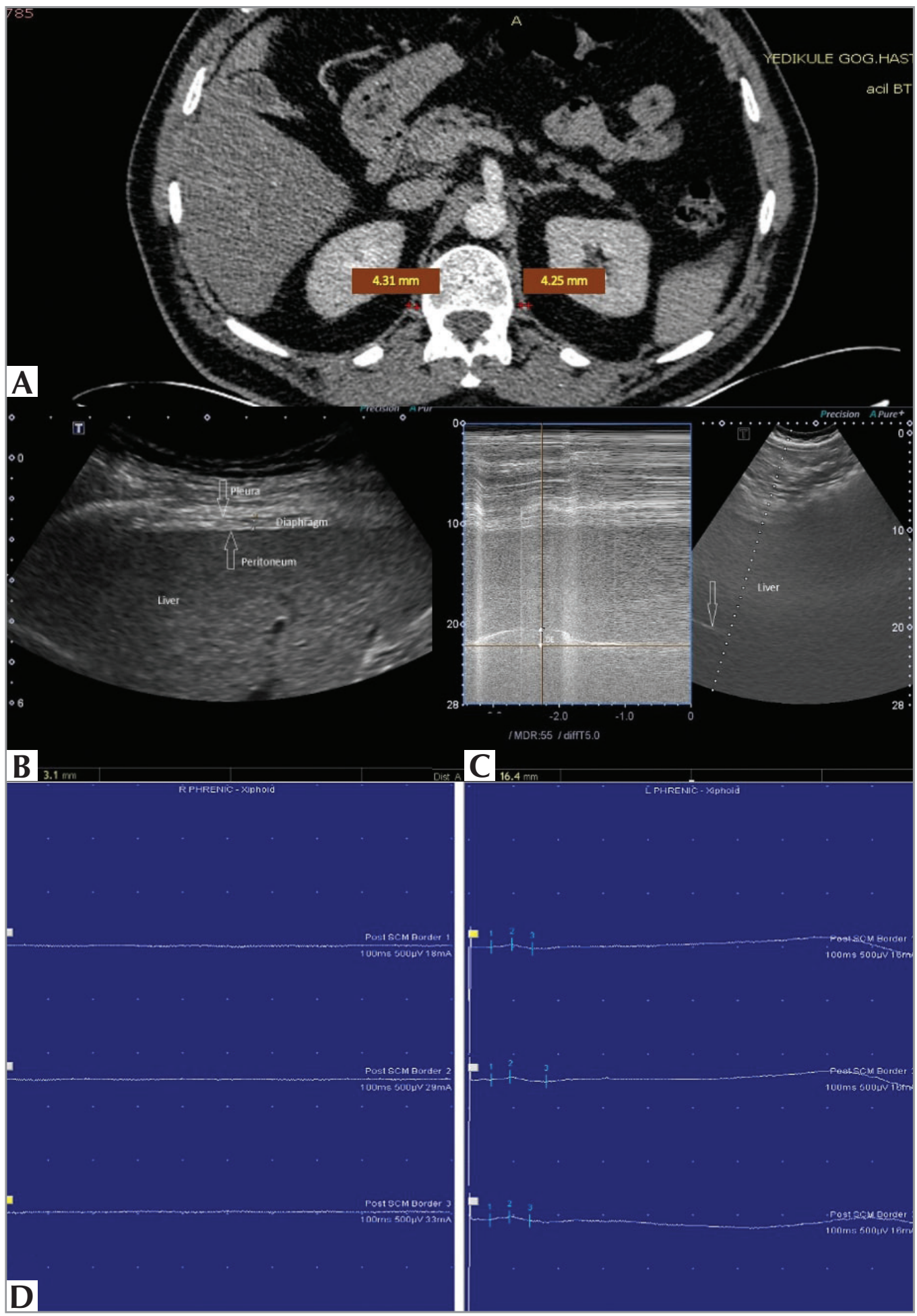

Figure 1. The sonographic and electromyographic and CT measurements of case 2, A. Measurement of the thickness of both diaphragm on thorax CT. B. B mode USG image showing three layer structure: two echogenic layers of peritoneum and pleura (white arrows), hypoechoic layer of the diaphragm between arrows. Measurement of the elevated diaphragm thickness; $3.1 \mathrm{~mm}$. C. Decreased right diaphragmatic excursion (DE) during deep inspirium; $16.4 \mathrm{~mm}$. D. Electromyography records showing no electrophysiological activity on the elevated diaphragm side. 
Table 1. Findings of sonographic. electromyographic measurements and spirometric parameters

\begin{tabular}{|c|c|c|c|c|c|c|}
\hline & Case 1 & Case 2 & Case 3 & Case 4 & Case 5 & Case 6 \\
\hline Sex & Female & Male & Female & Female & Male & Male \\
\hline Age (years) & 49 & 46 & 56 & 64 & 55 & 46 \\
\hline $\begin{array}{l}\text { Time after initial diagnosis } \\
\text { (months) }\end{array}$ & 3 & 3 & 6 & 4 & 4 & 4 \\
\hline FVC (It) & 3.55 & 5.66 & 2.33 & 1.91 & 2.70 & 3.32 \\
\hline FVC (\%) & 92 & 114 & 71 & 60 & 59 & 73 \\
\hline $\begin{array}{l}\text { USG- diaphragm motion } \\
\text { (visual) }\end{array}$ & Mobile & $\begin{array}{l}\text { Reduced } \\
\text { mobility }\end{array}$ & Mobile & $\begin{array}{l}\text { Reduced } \\
\text { mobility }\end{array}$ & Immobile & Mobile \\
\hline $\begin{array}{l}\text { USG- diaphragm thickness } \\
(\mathrm{mm}) \text { (lower limit: } 1.5 \mathrm{~mm} \text { [7]) }\end{array}$ & 2.70 & 3.10 & 3.10 & 2.60 & 3.40 & 2.80 \\
\hline $\begin{array}{l}\text { CT- diaphragm thickness }(\mathrm{mm}) \\
\text { [lower limit: } 1.5 \mathrm{~mm}(7)]\end{array}$ & 2.64 & 4.31 & 2.06 & $1.17^{*}$ & 3.5 & 2.74 \\
\hline $\begin{array}{l}\text { M mode USG- diaphragm } \\
\text { excursion }(\mathrm{mm}) \text { [lower limit: } \\
47 \mathrm{~mm} \text { for male. } 37 \mathrm{~mm} \text { for } \\
\text { female }(7)]\end{array}$ & 46 & $16.4^{*}$ & 55 & $34^{*}$ & $0^{*}$ & $41.5^{*}$ \\
\hline $\begin{array}{l}\text { EMG- mean DML in pCMAP } \\
\text { (right phrenic nerve) (ms) }\end{array}$ & $39.4 \pm 1.74^{*}$ & $N R^{*}$ & $4.08 \pm 0.06$ & $8.03 \pm 1.33^{*}$ & $8.68 \pm 0.19^{*}$ & $N R^{*}$ \\
\hline $\begin{array}{l}\text { EMG- mean DML in pCMAP } \\
\text { (left phrenic nerve) (ms) }\end{array}$ & $7.23 \pm 0.73$ & $3.88 \pm 0.49$ & $4.22 \pm 0.19$ & $6.42 \pm 0.56$ & $5.50 \pm 0.31$ & $5.43 \pm 0.06$ \\
\hline $\begin{array}{l}\text { EMG- mean amplitude in } \\
\text { pCMAP (right phrenic nerve) } \\
(\mu \mathrm{V})\end{array}$ & $150.60 \pm 31.84^{*}$ & $N R^{*}$ & $82.33 \pm 9.21^{*}$ & $538.2 \pm 98.09$ & $178.73 \pm 15.15$ & $N R^{*}$ \\
\hline $\begin{array}{l}\text { EMG- mean amplitude in } \\
\text { pCMAP (left phrenic nerve) } \\
(\mu \mathrm{V})\end{array}$ & $489.97 \pm 45.64$ & $78.33 \pm 12.05$ & $379.53 \pm 67.12$ & $622.5 \pm 54.31$ & $148.6 \pm 19.38$ & $403.63 \pm 26.27$ \\
\hline
\end{tabular}

\section{REFERENCES}

1. Ramani SL, Samet J, Franz CK, Hsieh C, Nguyen CV, Horbinski C, et al. Musculoskeletal involvement of COVID19: review of imaging. Skeletal Radiol 2021; 50(9): 176373.

2. Shi Z, de Vries HJ, Vlaar APJ, van der Hoeven J, Boon RA, Heunks LMA, et al. Dutch COVID-19 diaphragm investigators. Diaphragm pathology in critically ill patients with COVID-19 and postmortem findings from 3 medical centers. JAMA Intern Med 2021; 181(1): 122-4.

3. Van Steveninck AL, Imming LM. Diaphragm dysfunction prior to intubation in a patient with COVID-19 pneumonia; assessment by point of care ultrasound and potential implications for patient monitoring. Respir Med Case Rep 2020; 31: 101284.
4. Ertekin C. Sentral ve periferik EMG. Izmir: Meta Basım Matbaacılık Hizmetleri; 2006.

5. World Health Organization (WHO). COVID-19 Clinical management: living guidance. Available from: https:// www.who.int/publications/i/item/WHO-2019-nCoVclinical-2021-1 (Accessed date: 17 Apr 2021).

6. Crum-Cianflone NF. Bacterial, fungal, parasitic, and viral myositis. Clin Microbiol Rev 2008; 21(3): 473-94.

7. Dubé BP, Dres M. Diaphragm dysfunction: diagnostic approaches and management strategies. J Clin Med 2016; 5(12):113 